\title{
Clypeal excision in Tapinoma FöRSTER, 1850 ants is adaptive (Hymenoptera: Formicidae)
}

\author{
With 3 figures and 1 table
}

BERNHARD SEIFERT ${ }^{1}$

${ }^{1}$ Senckenberg Museum für Naturkunde Görlitz, Am Museum 1, 02826 Görlitz, Germany. - bernhard.seifert@senckenberg.de Published on 2016-06-30

\section{Summary}

Evidence is presented that the median clypeal excision in the dolichoderine ant genus Tapinoma FörSTER, 1850 is a rare adaptive trait improving the protrusion of mouthparts for better exploitation of food or water sources located in narrow cleft spaces. The problem of getting access to food from, for example, narrow tubes of nectaries becomes more serious with increasing worker head width. A regression analysis of species-specific means in 16 Westpalaearctic Tapinoma species shows that the relative depth of clypeal excision grows significantly with head width in the interspecific comparison $(p<0.001)$. Similar relations are also indicated on the intraspecific level for all species with the regression functions being significant on the $\mathrm{p}<0.025$ level. The clypeal cleft allows a sliding of the glossa and dorsomedian crests of the labial galeae in dorsofrontal direction.

\section{Key words}

Functional morphology, adaptive phenotypic trait, foraging biology, morphometry

\section{Zusammenfassung}

Die mediane Einkerbung des Clypeusvorderrandes bei Vertretern des Ameisengenus Tapinoma Förster, 1850 ist keine zufällig angelegte, selektionsneutrale Struktur sondern besitzt einen adaptivem Wert. Sie erlaubt ein weiteres Vorstrecken der Mundwerkzeuge und damit die bessere Aufnahme von Nahrung oder Wasser aus engen Spalträumen. Mit zunehmender Kopfbreite der Arbeiterinnen wird es immer schwieriger zum Boden solcher Spalträume, etwa der engen Röhren von floralen Nektarien, vorzudringen. Eine Regressionsanalyse der artspezifischen Werte von 16 westpaläarktischen Tapinoma-Arten zeigte, dass die Tiefe der Clypeuskerbe mit zunehmender Kopfbreite nicht nur absolut sondern insbesondere auch relativ zur Kopfbreite signifikant zunimmt ( $<<0.001)$. Ähnliche Beziehungen lassen sich auch intraspezifisch bei $69 \%$ der getesteten Arten für $\mathrm{p}<0.025$ nachweisen. Die Clypeuskerbe erlaubt ein Hindurchgleiten der Glossa und der dorsomedianen Kanten der Galeae des Labiums und damit eine Erweitung des Aktionsradius in dorsofrontaler Richtung.

\section{Introduction}

Ant taxonomists may ask themselves if some of the interspecifically variable phenotypical characters used for species delimitation are under selection or neutral.

There is no theory, for example, which difference in fitness could result if there are five or fifteen setae on pronotum of a Formica ant. One can certainly imagine 
that a regularly honey-combed or irregularly rugulose microsculpture on the vertex of a Cardiocondyla ant should influence mechanical stability of the cuticle and adhesion of particles or chemicals in a different way. Yet, can it make an adaptive or functional difference if there is a deeper or shallower clypeal excision in a Tapinoma worker while over $99 \%$ of the ant species worldwide do not show such a structure at all? The only function clypeal cleft seemed to have was not for ants: it was used in about a dozen of taxonomic papers from EMERY (1925) to SEIFERT (2012) as an informative character for species delimitation.

Rare and accidental observations often pave the road to awareness. Among some 1600 mounted Tapinoma workers in the collection of Senckenberg Museum of Natural History, there were two workers belonging to species of the Tapinoma nigerrimum (NyLANDER, 1856) complex that died in a posture with protruded mouthparts and opened mandibles. In one specimen, the glossa - a median, strongly rippled part of the labium (see figures 2-5 and 2-7 in Hölldobler \& Wilson 1990) - exactly fitted into the clypeal cleft (Fig. 2). There was some shrinking of the organ due to drying, the glossa is a little broader in its natural condition and the labium is much more extended, but basically the photo shows what should happen in living ants.

It is easily intelligible that a deep clypeal excision allows a farther dorsofrontal protrusion of the glossa and labium and allows a bigger amplitude of dorsoventral movements of these organs. Tapinoma ants use a variety of food sources (XERDA \& al. 1989, VerhaEghe \& al. 1992, SEIFERT 2007) - among these are liquids to be imbibed from narrow cleft spaces. A typical problem represents the extraction of nectar from diverse forms of tube-, funnel- or spur-shaped nectaries strongly narrowing towards the base. Such structures are developed in several plant families (HEGi 1957, 1966, 1979). The problem grows the larger the foraging ant is. A blocked broad-headed worker can only try to protrude its mouthparts as far as possible to get access to a liquid at the bottom of a microspace. As a consequence, large Tapinoma ants should adaptively develop not only absolutely but also relatively deeper clypeal excisions. This paper intends to check this hypothesis on the interspecific and intraspecific level based on morphometric data in Westpalaearctic Tapinoma species.

\section{Material and Methods}

Sixteen Tapinoma species with altogether 1146 workers were investigated. They belonged to T. erraticum (LATREILLE, 1798), T. nigerrimum (Nylander, 1856), T. pygmaeum (Dufour, 1857), T. magnum Mayr, 1861, T. madeirense FOREL, 1895, T. israelis FOREL, 1904, T. simrothi KrAUsSE, 1911, T. festae EMERY, 1925, T. ibericum SANTSCHI, 1925, T. karavaievi EMERY, 1925, T. phoeniceum EMERY, 1925, T. tauridis EMERY, 1925, T. kinburni Karavajev, 1937,
T. subboreale SEIFERT, 2012, Tapinoma spec. BALC (undescribed taxon) and Tapinoma spec. DARI (undescribed taxon). The specific numbers of investigated specimens are given in Tab. 1 in the Results and Discussion section.

The following measurements were taken in fully dried, mounted workers.

\section{CW maximum cephalic width}

CL maximum cephalic length between points $A$ and $\mathrm{B}$; $\mathrm{A}$ is the posteromedian margin point of head capsule; B is an imagined median point situated at the same transversal level as the most anterior points of clypeus left and right of the clypeal excision. Bilateral asymmetries are averaged.

ExCly Maximum depth of anteromedian clypeal excision as it appears in frontodorsal view; bilateral asymmetries are averaged.

Measuring was done under use of polarized-coaxial light illuminators and the high-resolution stereomicroscopes Wild M10 equipped with a $1.6 \mathrm{x}$ apochromatic objective and a Leica M165C equipped with a 2.0x apochromatic objective at magnifications of 120 to $240 \mathrm{x}$ (CW) and 320 to $350 \mathrm{x}$ (ExCly). The mean measuring error was estimated as $2.1 \mu \mathrm{m}$ in CW and $0.6 \mu \mathrm{m}$ in ExCly. The relative depth of clypeal excision is described as the per cent ratio of ExCly/CL.

The protrusion movements of the mouthparts were simulated in dead ethanol-stored worker ants by pulling with a fine forceps.

\section{Results and Discussion}

Tab. 1 shows the results of morphometric investigations. A regression of the species-specific means of clypeal depth index ExCly/CL against head width CW (Fig. 1) shows for fifteen species a highly significant positive correlation according to the function

ExCly/CL = 17.452 CW -5.918 (r=0.8160, p<0.001, $\mathrm{n}=16)$.

All species with mean $\mathrm{CW}<0.7 \mathrm{~mm}$ show a clypeal excision index smaller than $5.5 \%$ and the excision is extremely reduced in the nanitic T. pygmaeum. Ten out of eleven species with mean $\mathrm{CW}>0.7 \mathrm{~mm}$ show indices larger than $7.9 \%$. The only deviation is T. festae - an East Mediterranean species with completely unknown biology. The inclusion of mean values of two species with very low sample size in this regression is not suspected to provide a wrong picture in the interspecific comparison. The mean value of clypeal cleft index of $0.84 \%$ in Tapinoma pygmaeum based on only five measured specimens from three sites is confirmed by the available descriptions of this ant which report an extremely shallow or absent clypeal excision in an exceptionally small ant (ESPADALER 1977, CASENT0280679 in antweb.org). 
Tab. 1: Morphometric data of 16 West Palaearctic species of Tapinoma. Given are the species-specific means of cephalic width $\mathrm{CW}$, the clypeal excision index ExCly/CL and the slope A, intercept B, linear correlation coefficient R and significance level P of regressions of clypeal excision index against cephalic width.

\begin{tabular}{|l|c|c|c|c|c|c|c|}
\hline \multicolumn{1}{|c|}{ Species } & $\mathbf{n}$ & $\mathrm{CW}[\mathrm{mm}]$ & $\begin{array}{c}\text { ExCly/CL } \\
{[\%]}\end{array}$ & slope & intercept & $\mathrm{R}$ & $\mathbf{p}$ \\
\hline pygmaeum & 5 & 0.4345 & 0.82 & -0.15 & 0.884 & 0.0279 & n.s. \\
\hline kinburni & 7 & 0.5487 & 2.79 & -4.517 & 5.263 & 0.5028 & n.s. \\
\hline madeirense & 54 & 0.6490 & 4.58 & 2.639 & 2.863 & 0.2394 & 0.082 \\
\hline subboreale & 74 & 0.6653 & 4.79 & 1.410 & 3.855 & 0.1782 & n.s. \\
\hline israelis & 29 & 0.6729 & 5.47 & 5.253 & 1.939 & 0.6047 & 0.001 \\
\hline tauridis & 29 & 0.7115 & 8.56 & 3.472 & 6.088 & 0.3229 & 0.087 \\
\hline erraticum & 125 & 0.7220 & 7.97 & 6.613 & 3.200 & 0.7150 & 0.000 \\
\hline spec. BALC & 88 & 0.7474 & 9.15 & 6.890 & 4.002 & 0.6362 & 0.000 \\
\hline festae & 32 & 0.7842 & 3.69 & 1.878 & 2.219 & 0.396 & 0.025 \\
\hline phoeniceum & 82 & 0.8203 & 10.13 & 3.733 & 7.071 & 0.3398 & 0.002 \\
\hline simrothi & 102 & 0.8250 & 12.14 & 4.762 & 8.214 & 0.5428 & 0.000 \\
\hline spec. DARI & 119 & 0.8421 & 9.30 & 3.033 & 6.758 & 0.4796 & 0.000 \\
\hline karavajevi & 4 & 0.9214 & 11.40 & -4.430 & 15.484 & 0.6788 & n.s. \\
\hline magnum & 255 & 0.9241 & 8.58 & 1.979 & 6.756 & 0.3216 & 0.000 \\
\hline ibericum & 72 & 0.9842 & 9.96 & 2.163 & 7.828 & 0.4153 & 0.000 \\
\hline nigerrimum & 69 & 1.0050 & 9.91 & 0.093 & 9.815 & 0.0935 & n.s. \\
\hline
\end{tabular}

There are no literature data available to compare with the mean index of $11.4 \%$ calculated from four Tapinoma karavajevi workers but this data point is near to the trend line over all species (Fig. 1).

The within-species relations confirm a positive allometry of clypeal cleft index. All thirteen species with a sample size $>25$ workers show positive allometries. Nine of these functions are highly significant, two are weakly significant and one not significant (Tab. 1). The weakly positive slope and insignificance in T. nigerrimum is explained by an aberrant population in southern France.

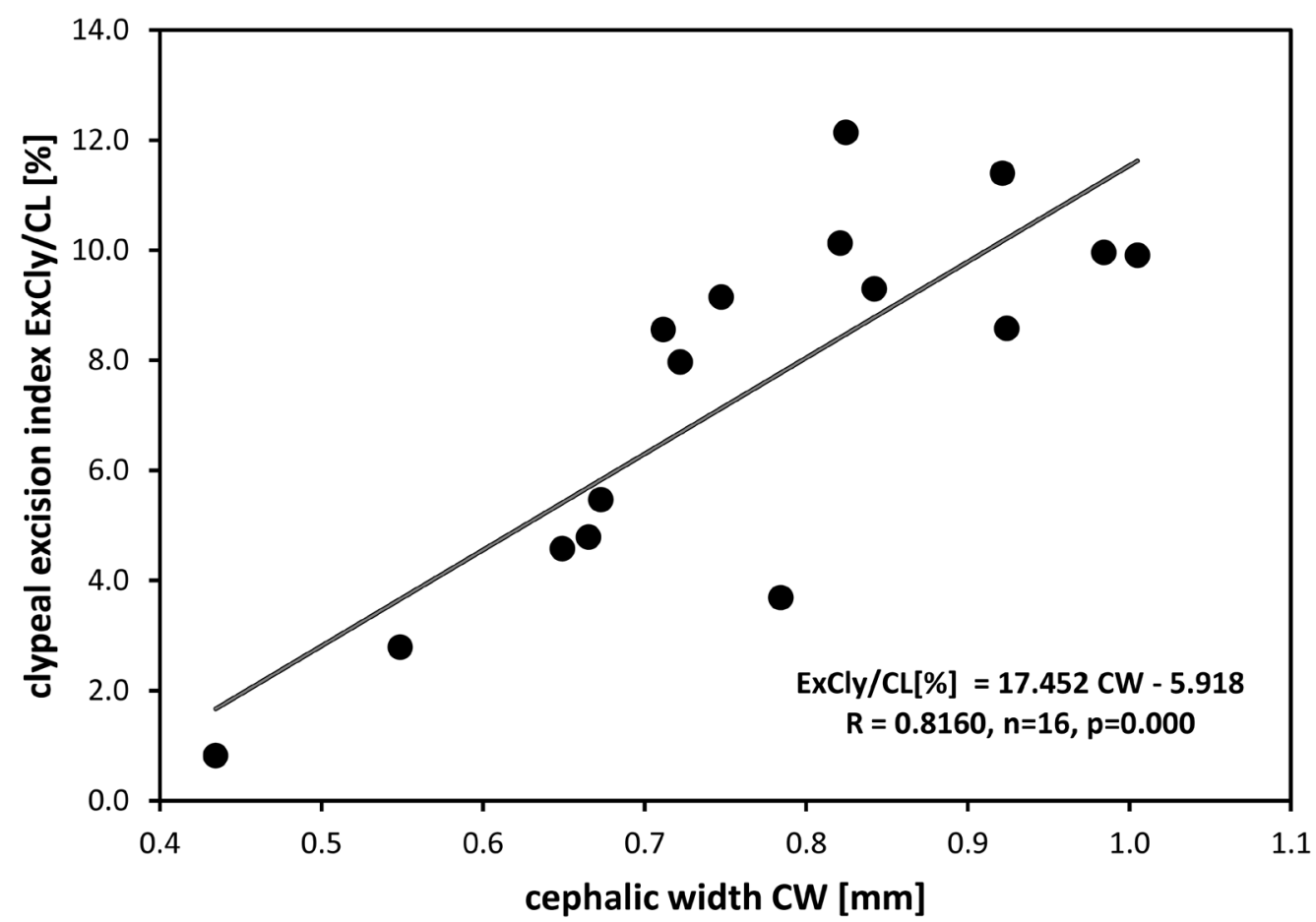

Fig. 1: Plotting of intraspecif mean of clypeal excision index ExCly/CL against intraspecific mean of cephalic width in workers of 16 Westpalaearctic Tapinoma species. 


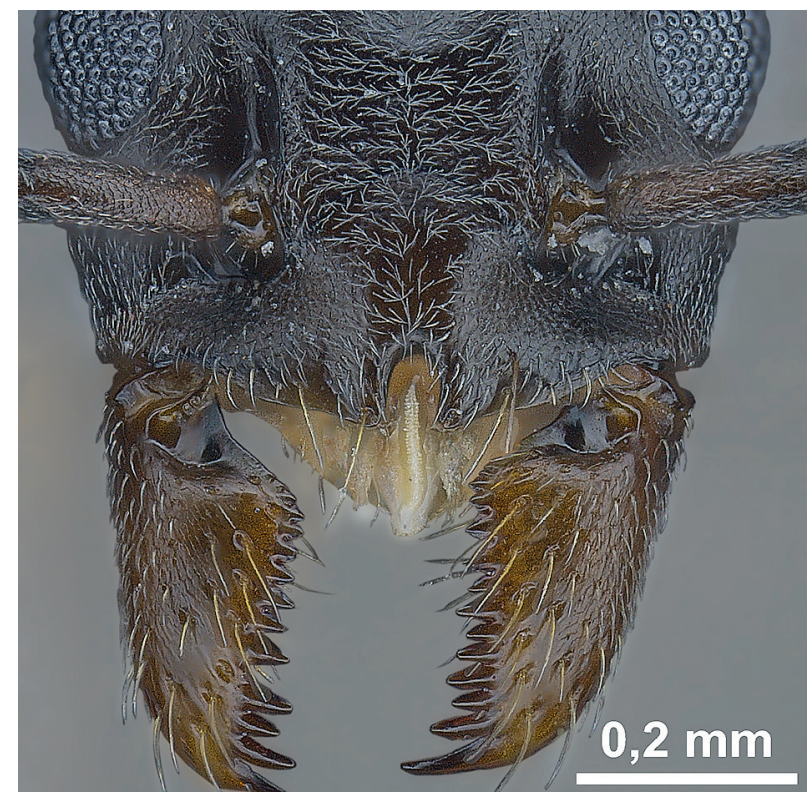

Fig. 2: Frontal head in a dry minor worker of Tapinoma magnum MAYr. The fitting of the glossa into the clypeal cleft shows a situation expected in an initial phase of dorsofrontal protrusion of mouthparts.

Simulating the movements in living ants by pulling mouthparts in dead, ethanol-stored specimens by a fine forceps led to the following conclusions. The cleft allows a protrusion of mouthparts into a more dorsofrontal direction. The glossa may slide through the cleft during the initial phase of this movement (Fig. 2) and the dorsomedian crests of the labial galeae (marked with black alignment in Fig. 3) during a later phase. During maximum protrusion in frontal direction, the tip of the glossa exceeds the tips of the half-opened mandibles.

These data support the hypothesis that the depth of the clypeal excision is modified in most Tapinoma species in an adaptive way to allow also broad-headed workers an exploitation of food sources from narrow cleft spaces. This solution appears less time- and energy-consuming than opening cleft spaces by force as it was observed, for example, in Myrmica ruginodis NyLANDER, 1856 which bites a hole in the bottom of the spur in Viola flowers to get access to the nectar (SEIFERT 2007). Furthermore, a non-destructive exploitation saves the plant and extends the time interval for use of a nectar source.

Well-developed clypeal excisions in other ants are known only in the related Dolichoderine genera Axinidris Weber 1941 and Technomyrmex MAYr 1872 (Shattuck 1991, Bolton 2007, SNELling 2007). The workers of all these genera mainly forage in the herb layer, on trees and on free surfaces but rarely in litter or soil. This was reported by XERDA \& al. (1989), VERHAEGHE \& al. (1992) and Seifert (2007) for Tapinoma, by Bolton (2007) for Technomyrmex, and by SNELling (2007) for Axinidris. Nectar from flowers is likely to represent a significant food source in all three genera.

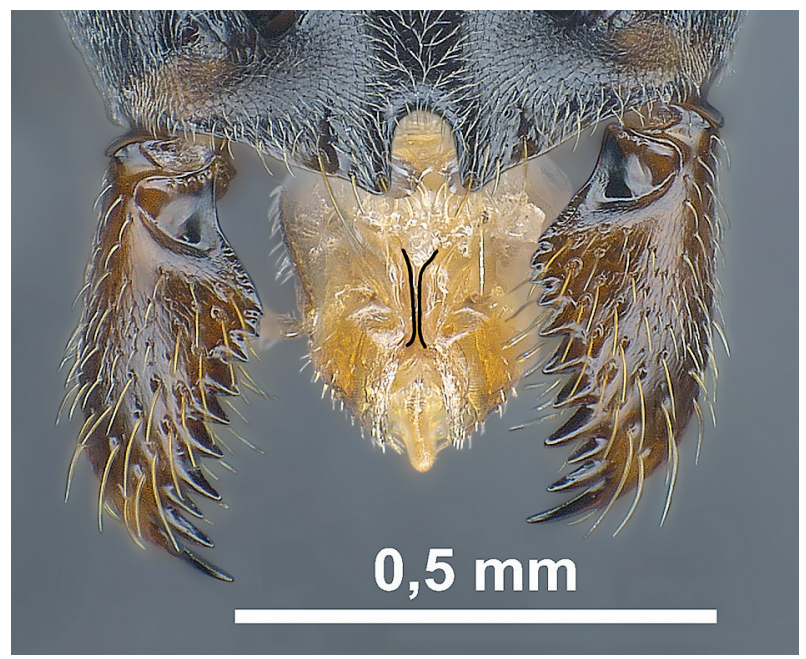

Fig. 3: Frontal head in a dry minor worker of Tapinoma ibericum SANTSCHI. The alignment of dorsomedian crests of the labial galeae are marked by black lines. They fit into the clypeal cleft during a later phase when the protrusion of mouthparts has a strong dorsal component.

While the functional morphology and principal advantage of a clypeal cleft is immediately intelligible from the mechanics of movement, it remains unclear how frequent the ants are confronted in nature with situations where this structure is really needed. Narrow bases of corolla tubes or tenuous flower spurs containing nectar are found in several plant families and some plant genera develop inside the flower special nectary leaves strongly narrowing towards the base (HEGI 1957, $1966,1979)$. However, it seems that nectaries with a very small basal lumen causing a blockade for ants with head widths of $>800 \mu \mathrm{m}$ are not frequent and the absence of a clypeal cleft in the vast majority of ants with a similar food selection and similar body size (such as Lasius) suggests a rather low fitness advantage of a clypeal cleft. The advantage could be more significant when water has to be extracted from impenetrable clefts. Tapinoma ants frequently live in strongly xerothermous habitats high above the ground water table and it may be important to get access to the last hidden residues of water. In the absence of any reasonable counter-hypothesis, I assume that the clypeal excision is a rare and special adaptive trait that evolved in a clade of Dolichoderine ants and is positively allometric at least in Tapinoma.

\section{Acknowledgements}

I wish to thank Roland Schultz from SMN Görlitz for providing the $\mathrm{z}$-stack photos. 


\section{References}

Bolton, B. 2007: Taxonomy of the Dolichoderine ant genus Technomyrmex MAYR (Hymenoptera: Formicidae) based on the worker caste. Contributions of the American Entomological Institute 35: 1-150.

EmerY, C. 1925: Revision des espèces paléarctiques du genre Tapinoma. - Revue Suisse de Zoologie 32: 45-64.

Espadaler, X. 1977: Descripción de los sexuados de Tapinoma pygmaeum (Dufour, 1857) (Hymenoptera, Formicidae). -Vie et Milieu 27: 119-128.

Hegi, G. 1957: Illustrierte Flora von Mitteleuropa. Volume III, part 1, 2nd edition. - Paul Parey, Berlin \& Hamburg.

HegI, G. 1966: Illustrierte Flora von Mitteleuropa. Volume IV, part 3, 2nd edition. - Weissdorn, Jena: $910 \mathrm{pp}$.

Hegi, G. 1979: Illustrierte Flora von Mitteleuropa. Volume III, part 2, 9th edition. - Paul Parey, Berlin \& Hamburg, 1979: 80 pp.

Hölldobler, B. \& Wilson, E. O. 1990: The ants. The Belknap Press of Harvard University Press, Cambridge, Massachusetts: XII + 732 pp.

SeIfert, B. 2007: Die Ameisen Mittel- und Nordeuropas. - Tauer: lutra-Verlags- und Vertriebsgesellschaft: $368 \mathrm{pp}$.
SeIfert, B. 2012: Clarifying naming and identification of the outdoor species of the ant genus Tapinoma Förster, 1850 (Hymenoptera: Formicidae) in Europe north of the Mediterranean region with description of a new species. - Myrmecological News 16: 139-147.

ShattuCK, S. O. 1991: Revision of Dolichoderine ant genus Axinidris (Hymenoptera: Formicidae). Systematic Entomology 16: 105-120.

SNELLING, R. R. 2007: A review of the arboreal Afrotropical ant genus Axinidris. - In: SNELLING, R. R.; Fisher, B. L. \& WARD, P. S. (eds.): Advances in ant systematics (Hymenoptera: Formicidae): homage to E. O. Wilson - 50 years of contributions. - Memoirs of the American Entomological Institute 80: 551-579.

Verhaeghe, J. C.; Salicaers, N.; Deneubourg, J. L. 1992: Nest-moving and food location in Tapinoma erraticum (Hymenoptera, Formicidae). - Biology and Evolution of Social Insects (J. Billen, ed.), Leuven University Press, Leuven: 335-342.

Xerda, X.; Retana, J.; Bosch, J. \& Alsina, A. 1989: Exploitation of food resources by the ant Tapinoma nigerrimum (Hymenoptera, Formicidae). - Acta Oecologica, Oecologia Generalis 10 (4): 419-429. 